\title{
Immunocytochemical evidence for extra-cellular initiation of elastase-induced bronchial secretory cell metaplasia in hamsters
}

\author{
T.G. Christensen, P.A. Alonso
}

Immunocytochemical evidence for extra-cellular initiation of elastase-induced bronchial secretory cell metaplasia in hamsters. T.G. Christensen, P.A. Alonso. CERS Journals Ltd 1996.

ABSTRACT: The bronchus is the only region of the hamster conducting airways to develop secretory cell metaplasia after an intratracheal instillation of human neutrophil elastase (HNE). We tested the hypothesis that this pathological change occurs because of cellular uptake of the enzyme that is specific to this region.

HNE, dissolved in saline, was instilled into the trachea of hamsters, that were sacrificed 5, 15, 30 or $60 \mathrm{~min}$ later for immunocytochemical localization of the enzyme. Saline-treated animals served as controls.

By light microscopy, HNE was evident only in the lumen and upon the epithelial surface in all airways, at all time points. Saline control tissues were negative. Electron microscopic immunogold staining revealed $\mathrm{HNE}$ within luminal macrophages and associated with mucus and, to a limited extent, upon the apical cell surface both in trachea and bronchus. A small amount of HNE staining occurred in the intercellular space and lamina propria of bronchi. Cytoplasmic gold particles were sparse both in treated and control animals.

We conclude that instilled neutrophil elastase is excluded from the epithelial cytoplasm regardless of region. We thus reject the hypothesis of airway cellular uptake of HNE and suggest that stimulation of bronchial secretory cells to accumulate mucin granules is initiated at the cell surface, possibly by unmasking or altering region-specific receptors involved in signal transduction pathways governing mucin granule synthesis.

Eur Respir J., 1996, 9, 535-541.
Mallory Institute of Pathology, and Dept of Pathology and Laboratory Medicine, Boston University School of Medicine, Boston, Massachusetts, USA.

Correspondence: T.G. Christensen Mallory Institute of Pathology

Boston University School of Medicine

784 Massachusetts Avenue

Boston

MA 02118

USA

Keywords: Bronchitis elastase

immunocytochemistry

mucus

Received: July 131995

Accepted after revision November 241995

This project was supported by NIH grant HL-19717 and by a MARC fellowship to P.A.
Hamsters exposed to an intratracheal instillation of the broad-spectrum, proteolytic enzyme, elastase, develop bronchial secretory cell metaplasia over a period of several weeks [1-5]. This epithelial alteration manifests microscopically as a cytoplasmic accumulation of mucin granules with an overlying luminal layer of mucus. It thus serves as a model of the epithelial component of clinical mucus hypersecretion seen in humans with disorders associated with airway inflammation, such as chronic bronchitis and cystic fibrosis [6-11].

The trachea and bronchioles of hamsters are spared from this pathological process $[3,12]$ for reasons that are unclear. Resistance does not appear to be related to a protective layer of glycoconjugates on the apical surface of epithelial secretory cells because the trachea is well-invested, whilst the bronchioles are not [13, 14]. Furthermore, resistance does not appear to be explained by a susceptible cell type found only in the bronchus because the predominant bronchial secretory cell type, though rare in the trachea, is abundant in bronchioles [14]. Regional dissimilarity in enzyme access to the cell surface does not seem to be a likely explanation because we have demonstrated that the glycoconjugate layer is altered by elastase in all airway regions [13, 14], suggesting that the enzyme comes into contact with the cells.

Conceivably, regional differences in cellular processing of the enzyme could explain our observations. The susceptible bronchial epithelial cells might internalize the enzyme as a key step in mucin granule upregulation, whilst cells in resistant regions might not take up the enzyme. This hypothesis was tested in the present study by immunolocalization of the enzyme in the conducting airways at four time-points within the first hour after instillation.

\section{Material and methods}

Localization of instilled elastase was studied by exposing 12 young adult male Syrian hamsters (100-120 g), whilst under carbon dioxide-induced anaesthesia, to an intratracheal instillation of our standard metaplasia-producing dose of $300 \mu \mathrm{g}$ human neutrophil elastase (HNE) (Calbiochem) dissolved in $0.5 \mathrm{~mL}$ physiological saline [5]. An equal number of animals, instilled with saline, served as controls. 
At 5, 15, 30 and $60 \mathrm{~min}$ after exposure, three animals from each group were anaesthetized with sodium pentobarbital and sacrificed by section of the abdominal aorta. The trachea was tied below the larynx and the lungs were perfusion-fixed through the right ventricle with a mixture of $4 \%$ commercial formalin/1\% glutaraldehyde in $0.1 \mathrm{M}$ cacodylate buffer $(4 \mathrm{CF}-1 \mathrm{G})$ at room temperature. This fixative was selected from among five fixatives initially tested for optimal cellular preservation combined with elastase antigenic sensitivity within azurophilic granules of neutrophils in sections of leucocytes obtained from centrifuged human blood and embedded in LR White (Polysciences).

The trachea and lungs were removed from the thorax and placed in fixative overnight at room temperature. The lungs were cut into small portions containing the main intrapulmonary bronchi (defined as having a calibre greater than $0.5 \mathrm{~mm}$ ) and bronchioles (calibre $<0.5$ $\mathrm{mm}$ ). These tissues and cross-sections of mid to lower trachea were dehydrated in ethanol, embedded in LR White and polymerized at $60^{\circ} \mathrm{C}$ for $24 \mathrm{~h}$. Other groups of hamsters were similarly exposed and then fixed by intravascular perfusion with $10 \%$ neutral buffered formalin. The ligated trachea and lungs were removed, immersed in the same fixative for $40 \mathrm{~h}$ at room temperature, and embedded in paraffin.

\section{Immunohistochemistry}

Paraffin-embedded tissues were cut at a thickness of $4 \mu \mathrm{m}$ and the slides deparaffinized in xylene. These slides and slides containing $2 \mu \mathrm{m}$-thick sections of LR Whiteembedded tissue were incubated in $3 \%$ hydrogen peroxide in water for $10 \mathrm{~min}$. Nonspecific binding was blocked with a 30 min incubation in $1 \%$ normal goat serum in $0.05 \mathrm{M}$ Tris buffer, $\mathrm{pH}$ 7.6. After blotting excess serum from the sections, they were stained in a moist chamber at room temperature with a 1:75 dilution (in $0.05 \mathrm{M}$ Tris buffer, $\mathrm{pH}$ 7.6) of the monoclonal mouse anti-HNE antibody (NP-57; Dako) with $1 \%$ fatty acidfree bovine serum albumin (BSA; Gibco) for $1 \mathrm{~h}$. Sections were rinsed $3 \times 3 \mathrm{~min}$ in buffer and then incubated for $10 \mathrm{~min}$ with biotinylated rabbit anti-mouse antibody (K686; Dako), followed by a 5 min incubation in avidinperoxidase conjugate (Dako). After a $10 \mathrm{~min}$ rinse in buffer, sections were incubated for $3 \mathrm{~min}$ in $0.1 \% 3,3^{\prime}-$ diaminobenzidine (DAB) tetrahydrochloride and $0.01 \%$ hydrogen peroxide per $5 \mathrm{~mL}$ of DAB in buffer, rinsed in buffer, incubated for $5 \mathrm{~min}$ in distilled water, and viewed in the microscope with or without a methyl green counterstain.

For immunoelectron microscopy of LR White-embedded tissues, 2 um thick sections that showed HNE immunopositivity were selected. Thin sections were then cut from the appropriate area on the corresponding blocks and were placed on collodion-coated 200 mesh nickel grids. The grids were submerged for $2 \mathrm{~h}$ at room temperature in a drop of a 1:50 dilution of mouse monoclonal anti-HNE antibody (NP-57; Dako) with $1 \%$ BSA in phosphate-buffered saline (PBS). Grids were rinsed in $20 \mathrm{mM}$ Tris buffer ( $\mathrm{pH} 8.2$ ) and stained for $2 \mathrm{~h}$ with a 1:50 dilution (in Tris buffer) of $10 \mathrm{~nm}$ gold-conjugated rabbit anti-mouse polyclonal immunoglobulin $\mathrm{G}$ (Dako), and rinsed $5 \times 2 \mathrm{~min}$ in water. Grids were then stained with $1 \%$ uranyl acetate and rinsed in distilled water before examination in the electron microscope.

\section{Image analysis}

Electron micrographs of saline and elastase-treated bronchial secretory cells were analysed quantitatively to determine whether the number per unit area of any cytoplasmic gold particles in the two groups was similar or significantly different. Using a Chromachip II videocamera (Javelin Electronics) and Optimas computer program (BioScan Inc.), $6 \times 8 \mathrm{~cm}$ images of supranuclear cytoplasm of secretory cells with at least one cytoplasmic gold particle were captured from randomly selected electron micrographs enlarged to a final print magnification of $\times 45,000$. The images were displayed on a 14 inch Sony video-monitor. Cytoplasmic boundaries were traced electronically, and the areas included then calculated by the program. Gold particles were counted manually and expressed as number of gold particles per unit area of cytoplasm in 75 or more cells at each time-point.

\section{Controls}

Saline-treated animals served as negative controls both for immunoperoxidase and immunogold staining. Omission of the primary antibody as well as replacement with an antibody to bacterial cell wall glycoprotein (Oncogene Sciences Inc.) were also used in both methods. For positive controls, leucocytes isolated from human blood were fixed at room temperature for $24 \mathrm{~h}$ in $4 \mathrm{CF}-1 \mathrm{G}$, centrifuged at $100 \times \mathrm{g}$, suspended in $2 \%$ agar at $45^{\circ} \mathrm{C}$, and applied as a drop to a glass slide. After hardening at room temperature, pieces of the agar-encapsulated leucocytes were dehydrated in a graded ethanol series, embedded in LR White, and polymerized at $60^{\circ} \mathrm{C}$ for $24 \mathrm{~h}$. Thin sections were obtained and immunostained, as detailed above, to localize elastase in azurophilic granules at the ultrastructural level.

\section{Results}

Light microscopic observation of immunostained paraffin sections of HNE-exposed hamsters demonstrated widespread elastase signal directly above the epithelium in all regions of the conducting airways (fig. 1). Saline control tissues were uniformly negative (fig. 2). The amount of immunoreaction product in the airway lumen did not appear to change appreciably with time. Immunostaining was associated with luminal mucus and with what appeared to be macrophages in close apposition with the apical surface of epithelial cells (fig. 3). The intensity of the staining did not differ among airway regions. Immunoreaction product was not seen within, 

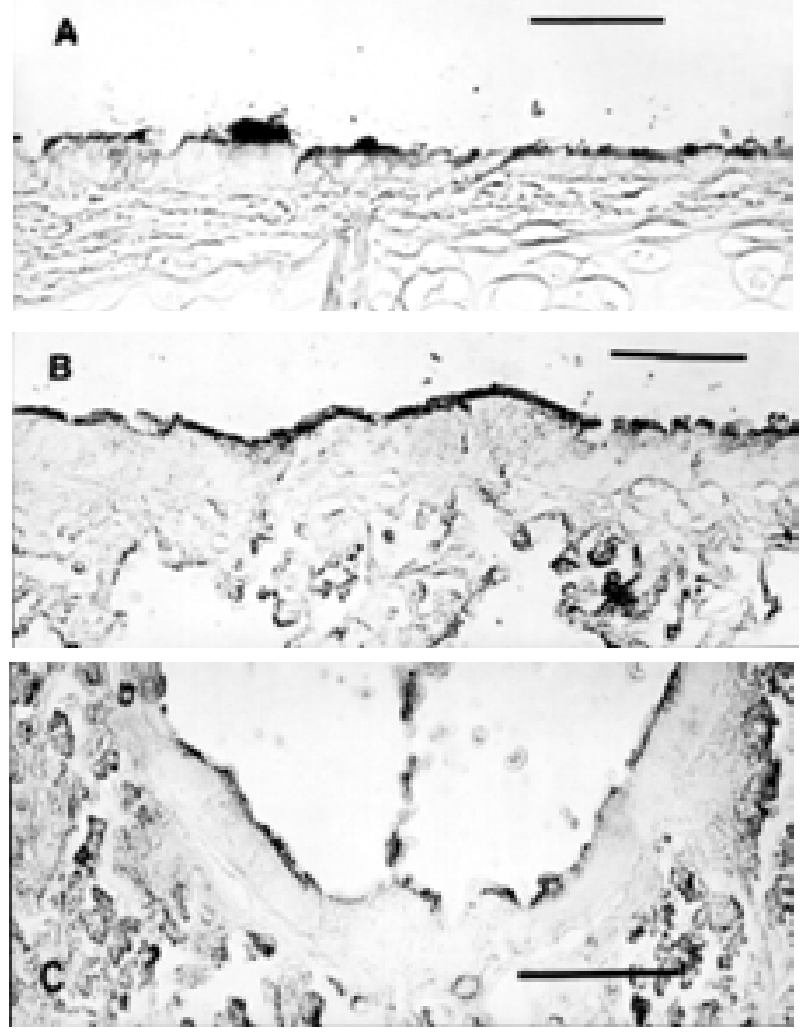

Fig. 1. - Paraffin sections of hamster: A) trachea; B) bronchus; and C) bronchiole, demonstrating immunoperoxidase staining of human neutrophil elastase above the epithelium $5 \mathrm{~min}$ after intratracheal instillation. Similar images were seen at 15, 30 and $60 \mathrm{~min}$. (Internal scale bar=50 $\mu \mathrm{m})$.
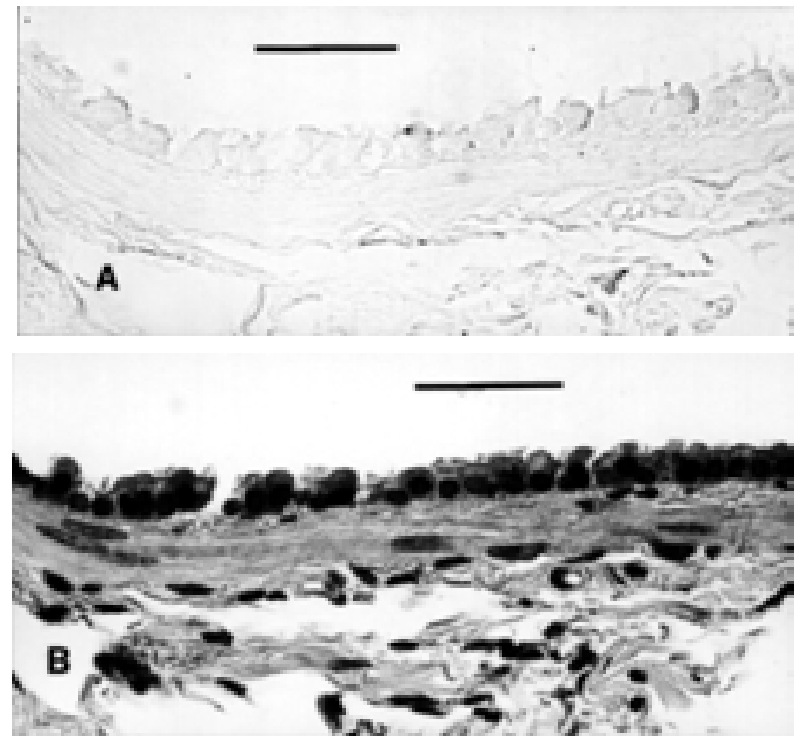

Fig. 2. - Paraffin sections of bronchial epithelium from saline-treated control hamster showing: A) negative immunostaining for human neutrophil elastase and; B) for orientation, the matching area in a serial section stained with haematoxylin and eosin. (Internal scale bar=50 $\mu \mathrm{m})$

between or beneath airway epithelial cells in any region at any time by light microscopy of paraffin or LR Whiteembedded tissues. Immunocontrol slides were consistently negative at all time-points.
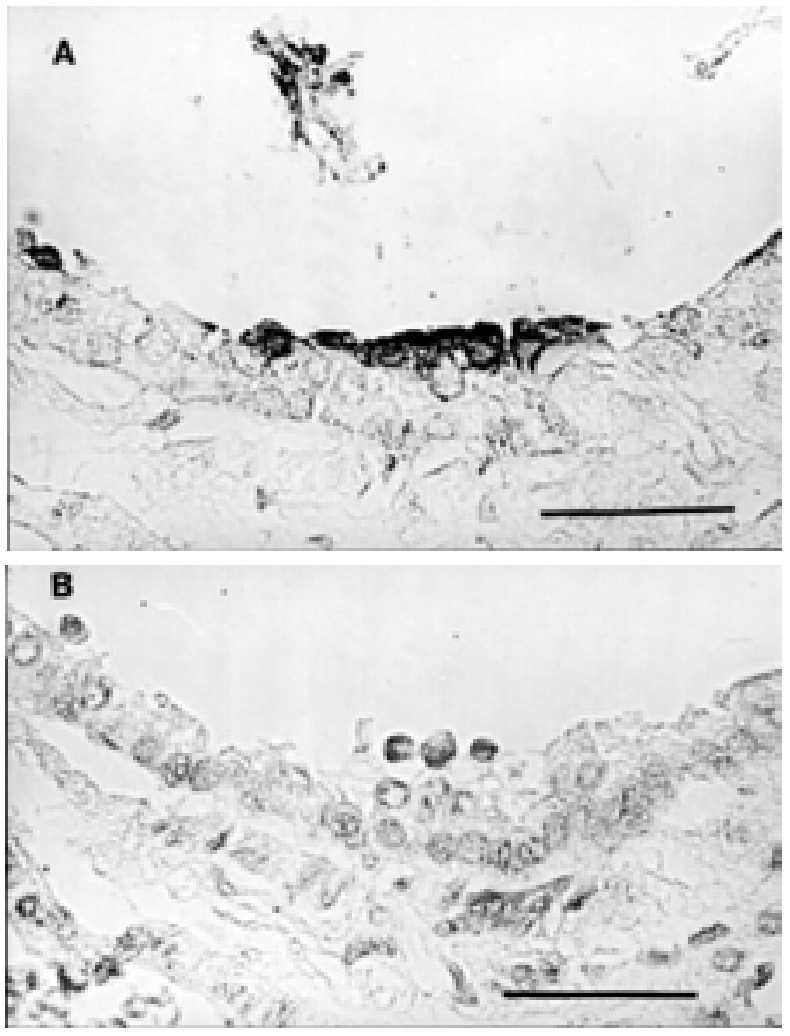

Fig. 3. - Paraffin sections of human neutrophil elastase (HNE)instilled hamster lung illustrating: A) positive immunostaining for $\mathrm{HNE}$ in the luminal mucus layer and macrophages; and B) negative reaction when primary antibody to HNE was omitted in the adjacent control section. (Internal scale bar=50 $\mu \mathrm{m}$ ).

Immunoelectron microscopy of HNE-treated animals revealed gold particles in association with airway luminal mucus at all time-points (fig. 4). Gold particles were also seen in the phagocytic vacuoles of macrophages (fig. 5). These particles were not seen in macrophages and mucus of saline-treated animals. The specificity of the immunoreaction for HNE was confirmed by the presence of gold particles on the intracytoplasmic granules of human neutrophils in sections of pelleted leucocytes (fig. 6). Hamster neutrophils, which are known to contain elastase [15], did not cross-react with the antibody

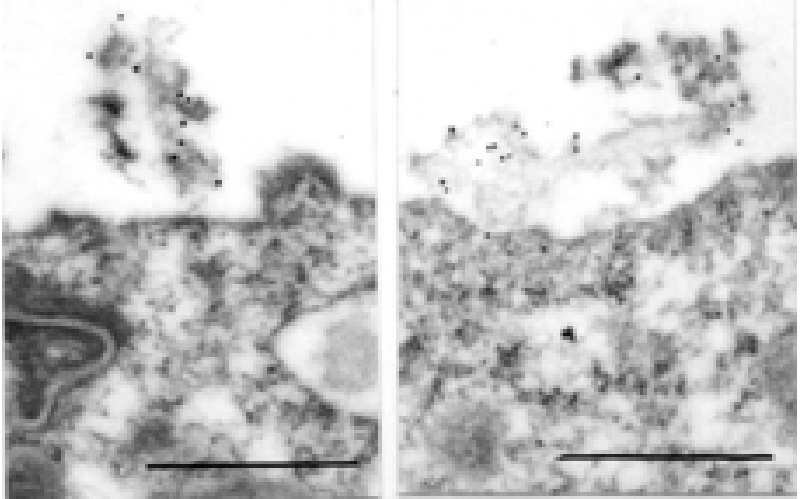

Fig. 4. - Electron micrographs of hamster bronchus showing immunogold localization of human neutrophil elastase associated with luminal mucus $5 \mathrm{~min}$ after instillation. (Internal scale bar=0.5 $\mu \mathrm{m}$ ). 


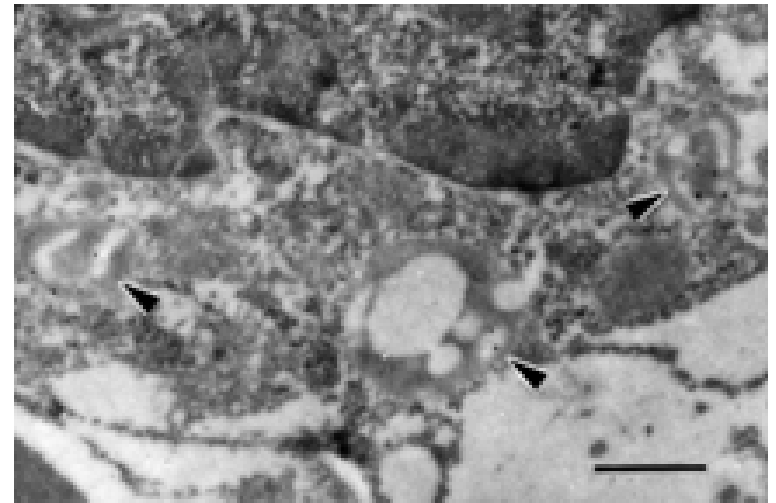

Fig. 5. - Immunogold staining of human neutrophil elastase (HNE) in the phagocytic vacuoles (arrowheads) of a macrophage in the lumen of a hamster bronchus $15 \mathrm{~min}$ after HNE instillation. Macrophages in saline control animals were invariably negative. (Internal scale bar $=0.5 \mu \mathrm{m}$ )

\section{to HNE.}

Immunogold particles were occasionally seen in direct contact with the apical cell membrane both in trachea and bronchus at all time-points (fig. 7). In a few instances, the intercellular space between bronchial, but not tracheal, epithelial cells contained gold particles (fig. 8A). HNE staining was seen focally in association with subepithelial elastin in the bronchus but not trachea (fig. 8B). Saline-treated control lungs showed sparse and randomly-distributed gold particles not obviously associated

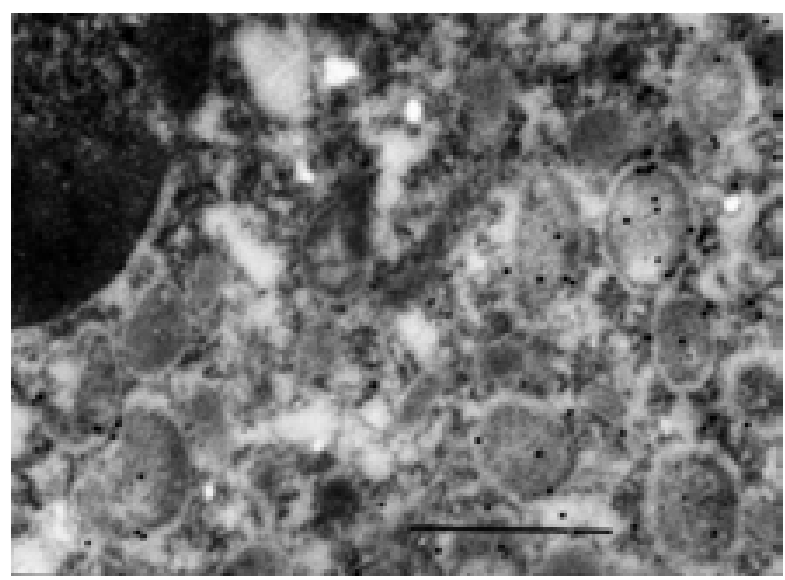

Fig. 6. - Positive control specimen demonstrating immunogold staining of elastase in the cytoplasmic granules of a human polymorphonuclear leucocyte. (Internal scale bar=0.5 $\mu \mathrm{m}$ ).

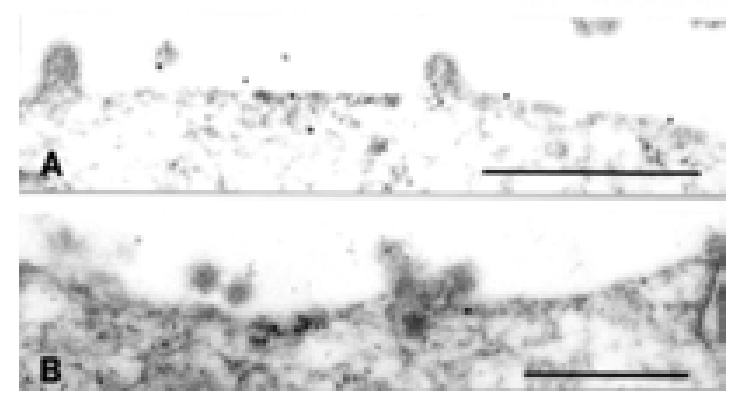

Fig. 7. - Immunogold localization of a small amount of human neutrophil elastase on the apical surface of nonciliated epithelial cell in: A) trachea; and B) bronchus. Images such as these were seen at all time-points. (Internal scale bar=0.5 $\mu \mathrm{m}$ ).
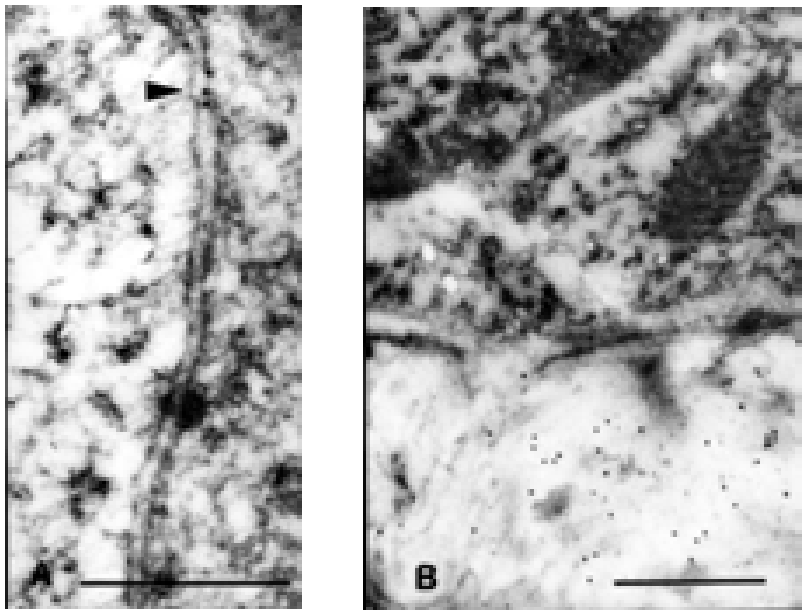

Fig. 8. - Immunogold localization of human neutrophil elastase in hamster bronchus showing gold particles: A) (arrowhead) in the intercellular space (arrowhead); and B) on subepithelial elastin. The trachea lacked staining in these compartments. (Internal scale bar=0.5

with any particular airway region or cellular compartment.

Occasional gold particles were seen over the cytoplasm of airway epithelial cells in HNE-treated animals but their number did not appear to exceed the background staining seen in the saline control animals. Before we could reject the hypothesis that bronchial epithelial cells are susceptible to HNE because of cellular uptake, in contrast to cells in resistant regions, it was necessary to confirm this observation by performing a quantitative analysis of gold particle number per unit area. Cytoplasmic gold particles were counted and the area determined by computerized image analysis. This permitted a gold particle number per unit area calculation, which was used in a comparison of values for saline and HNE. The results (table 1) indicate that at no time was there a difference between saline and HNE either in the proportion of cells containing cytoplasmic gold particles or the number per unit area of gold particles. Similarly, quantitative analysis of epithelial cells lining the resistant trachea confirmed that gold particles were not significantly greater in number in HNE-treated animals compared to saline controls (data not shown). Bronchiolar epithelial cells were not analysed quantitatively by immunoelectron microscopy because they did not appear to be different from tracheal and bronchial epithelial cells.

\section{Discussion}

The key result of this study is the demonstration of an absence of HNE signal within airway epithelial cells, regardless of region. We think it unlikely that uptake occurs later than $1 \mathrm{~h}$ after instillation, based on our previous work showing rapid endocytosis of horseradish peroxidase by hamster airway epithelial cells [16]. It seems equally unlikely that the enzyme is taken up by endocytosis and quickly rendered immunonegative by lysosomal action. Elastase is known to be immunopositive after endocytosis by intestinal epithelial cells [17]. Furthermore, we noted HNE immunopositivity within alveolar macrophages, which we interpreted as indicat- 
Table 1. - Comparison of immunogold staining in the cytoplasm of bronchial epithelial cells after saline or elastase exposure

\begin{tabular}{|c|c|c|c|c|c|c|c|c|}
\hline \multirow{3}{*}{$\begin{array}{l}\text { Time } \\
\text { min }\end{array}$} & \multicolumn{5}{|c|}{$\begin{array}{c}\text { Cells with } \geq 1 \\
\text { cytoplasmic gold particles }\end{array}$} & \multicolumn{3}{|c|}{ Density of cytoplasmic gold particles\# } \\
\hline & \multicolumn{2}{|c|}{ Saline } & \multicolumn{2}{|c|}{ Elastase } & \multirow[t]{2}{*}{ p-value ${ }^{+}$} & \multirow[t]{2}{*}{ Saline } & \multirow[t]{2}{*}{ Elastase } & \multirow[t]{2}{*}{ p-values } \\
\hline & $\%$ & $(\mathrm{n})^{*}$ & $\%$ & $(\mathrm{n})^{*}$ & & & & \\
\hline 5 & 16 & $(63)$ & 11 & (88) & NS & $5.4 \pm 2.8$ & $4.0 \pm 1.4$ & NS \\
\hline 15 & 39 & (28) & 37 & (183) & NS & $4.4 \pm 1.7$ & $4.8 \pm 2.4$ & NS \\
\hline 30 & 25 & (28) & 16 & $(86)$ & NS & $4.8 \pm 2.7$ & $7.8 \pm 9.8$ & NS \\
\hline 60 & 17 & (18) & 12 & $(66)$ & NS & $5.8 \pm 2.0$ & $8.5 \pm 3.1$ & NS \\
\hline
\end{tabular}

\#: mean \pm SD of gold particles $\left(\times 10^{-2}\right)$ per $\mu^{2}$ of nonnuclear cytoplasm in cells with $\geq 1$ cytoplasmic gold particles; ${ }^{+}$: saline versus elastase compared by Chi-squared test of actual proportions; \$: saline versus elastase compared by Student's t-test. *: total cells examined.

ing uptake of instilled enzyme because of the lack of reactivity in macrophages in saline-treated control animals. HNE immunoreactivity within alveolar macrophages has been demonstrated previously $[18,19]$, but the airway epithelium received no mention in these studies. Uptake by alveolar macrophages has been shown to be receptor-mediated [20]. Receptors for elastase uptake are also present on neutrophils [21], and cultured chondrocytes [22]. Whilst our results do not exclude the possible presence of elastase receptors on airway epithelial cells, they argue against receptor-mediated uptake of elastase.

There was little difference between the trachea and the bronchus regarding localization of instilled HNE in the airway lumen. Although the light microscopic examination showed what appeared to be surface contact by the enzyme, electron microscopy demonstrated that much of this was mucin-associated and very little was found in direct contact with the cell surface both in trachea and bronchus. However, we previously reported that the surface glycoconjugate layer is altered within $20 \mathrm{~min}$ of HNE instillation [13], and the bronchial cells are stimulated to discharge and accumulate secretory granules over a 3 week period $[5,23]$. We had interpreted this to suggest surface contact of HNE with the cells as a triggering force in upregulation of mucus glycoprotein synthesis. It is unclear, therefore, why so little activity was detected on the cell surface in the present study. Conceivably, stimulation of bronchial cells by surface contact is quite brief and, subsequently, the enzyme is bound more avidly to luminal mucin. HNE is a basic glycoprotein [24] and mucin, which is negatively charged due to its content of sialic acid and sulphate groups, is a target for enzymatic degradation by HNE [25]. The possibility that HNE may be rendered immunologically negative by surface-associated mucus [26], or by sulphated glycoconjugates [27, 28], cannot be ruled out.

If $\mathrm{HNE}$ is not taken up by the bronchial secretory cells, how then does it upregulate mucus glycoprotein synthesis? It may act at the apical or lateral cell surface by altering or degrading plasma membrane receptors involved in mucus secretory activity. Endogenous bioactive substances, such as platelet-activating factor and adenosine triphosphate, are thought to cause mucus secre- tion from airway secretory cells by binding to receptors on the cell membrane and transducing a signal culminating in discharge of granules [29-33]. Elastase can attack surface receptors on a variety of cell types, including epithelial cells [34-37]. Ineffective receptor signalling might, therefore, cause an accumulation of granules because their synthesis outpaces the rate of secretion; this would result in the morphological appearance of secretory cell metaplasia.

Alternatively, HNE may upregulate mucus synthesis by exposing cell surface sites responsive to external factors that modulate mucus synthesis by signal transduction. The mucus coat on the apical cell surface may act normally as a negative feedback regulator by masking receptors for ligands that trigger a cascade of metabolic events that upregulate mucus synthesis. A key ligand in this process may be transforming growth factor-beta. Airway epithelial cells produce it, possess surface receptors for it and, under the correct conditions, adopt a goblet cell phenotype in response to it [38]. HNE is capable of degrading cell surface mucin [25] and mucin-like molecules $[39,40]$, which can lead to an alteration in cell function. The bronchus may be more susceptible to HNE than the trachea because it has more receptors or a thinner cell surface coat of glycoconjugates compared to the trachea [13]. Resistance of bronchiolar epithelial cells, which also have a thin glycoconjugate coat [14], may result from an absence of the receptors necessary for upregulation of mucus secretory products.

Our results demonstrated the presence of a small amount of HNE between bronchial epithelial cells. It is unclear why antibody staining revealed the enzyme in the intercellular space by electron microscopy but not by light microscopy. Conceivably, this compartment is too narrow to show a small amount by light microscopy but the combined resolution and sensitivity of the ultrastructural method was sufficient to reveal it. The enzyme may have gained access to this region by attacking epithelial tight junctions. Intercellular gaps have been shown to occur between monolayers of cultured airway epithelial cells exposed to elastase [41-43]. A sublethal exposure of elastase to the apical surface of a confluent and electrically resistant monolayer of bovine bronchial epithelial cells caused detachment of $11 \%$ of the cells [44], possibly by penetrating the tight junctions known to 
form in airway epithelial cell culture [45, 46].

Enzymatic alteration and penetration of tight junctions may explain the appearance of HNE in association with subepithelial elastin in the present study. In addition to elastin, HNE can degrade other structural components in this region, including collagen types I-IV, laminin, fibronectin and proteoglycans [24, 47, 48]. Proteolytic degradation of extracellular matrix involved in epithelial attachment may explain the epithelial desquamation seen focally in hamster lungs exposed to elastase in vivo [1], and the detachment of epithelial cells from elastase-treated human respiratory mucosal biopsies in vitro [49].

The presence of extracellular neutrophil elastase in the lamina propria of hamster bronchi and in asthmatic patients [50] supports the concept that neutrophil proteases may cause epithelial detachment by direct action at substrate sites that play a role in airway wall integrity. This has important implications for the pathogenesis of diseases involving airway inflammation, such as asthma, chronic bronchitis and cystic fibrosis.

Acknowledgements: The authors thank C. Mack for technical assistance.

\section{References}

1. Christensen TG, Korthy AL, Snider GL, Hayes JA. Irreversible bronchial goblet cell metaplasia in hamsters with elastase-induced panacinar emphysema. J Clin Invest 1977; 59: 397-404.

2. Hayes JA, Christensen TG. Bronchial mucus hypersecretion induced by elastase in hamsters: ultrastructural appearances. J Pathol 1978; 125: 25-31.

3. Snider GL, Lucey EC, Christensen TG, et al. Emphysema and bronchial secretory cell metaplasia induced in hamsters by human neutrophil products. Am Rev Respir Dis 1984; 129: 155-160.

4. Breuer R, Christensen TG, Lucey EC, Stone PJ, Snider GL. Quantitative study of secretory cell metaplasia induced by human neutrophil elastase in the large bronchi of hamsters. J Lab Clin Med 1985; 105: 635-640.

5. Christensen TG, Breuer R, Hornstra LJ, Lucey EC, Stone PJ, Snider GL. An ultrastructural study of the response of hamster bronchial epithelium to human neutrophil elastase. Exp Lung Res 1987; 13: 279-297.

6. Lev R, Spicer SS. A histochemical comparison of human epithelial mucins in normal and in hypersecretory states, including pancreatic cystic fibrosis. Am J Pathol 1965; 46: $23-47$.

7. Tos M, Moller K. Goblet-cell density in human bronchus in chronic bronchitis. Arch Otolaryngol 1983; 109: 673676.

8. Reid L, Jones R. Experimental chronic bronchitis. Int Rev Exp Path 1983; 24: 335-383.

9. Wunderlich P, Kemmer C, Fischer R, et al. Bronchial secretions and bronchial mucosa in children with cystic fibrosis: comparison of bronchoscopic, biochemical, bacteriological, microscopic and ultrastructural findings. Acta Paediatr Hung 1986; 27: 123-131.

10. Lundgren JD, Shelhamer JH. Pathogenesis of airway mucus hypersecretion. J Allergy Clin Immunol 1990; 85: 399-419.

11. Trevisani L, Sartori S, Bovolenta MR, et al. Structural characterization of the bronchial epithelium of subjects with chronic bronchitis and in asymptomatic smokers. Respiration 1992; 59: 136-144.

12. Christensen TG, Breuer R, Lucey EC, Stone PJ, Snider GL. Regional difference in airway epithelial response to neutrophil elastase: tracheal secretory cells discharge and recover in hamsters that develop bronchial secretory cell metaplasia. Exp Lung Res 1989; 15: 943-959.

13. Christensen TG, Breuer R, Lucey EC, Hornstra LJ, Stone PJ, Snider GL. Lectin cytochemistry reveals differences between hamster trachea and bronchus in the composition of epithelial surface glycoconjugates and in the response of secretory cells to neutrophil elastase. Am J Respir Cell Mol Biol 1990; 3: 61-69.

14. Christensen TG, Breuer R, Haddad CE, Lucey EC, Stone PJ, Snider GL. Resistance of hamster bronchiolar epithelium to neutrophil elastase: investigation by cell surface lectin cytochemistry. Exp Lung Res 1992; 18: 115-129.

15. Boudier C, Bieth JG. Estimation and characterization of hamster leukocyte elastase. Biochem Med 1982; 28: 41-50.

16. Christensen TG, Janeczek AH. Response of the tracheobronchial epithelium to hemoprotein tracers. Lung 1985; 163: 95-108.

17. Tsujii T, Akita M, Katayama K, Yamamoto S, Seno S. Absorption of elastase through the jejunal mucosa of the rat: an immunocytochemical study. Histochemistry 1984; 81: 427-433.

18. Janoff A, Sloan B, Weinbaum G, et al. Experimental emphysema induced with purified human neutrophil elastase: tissue localization of the instilled protease. Am Rev Respir Dis 1977; 115: 461-478.

19. Sandhaus RA, Janoff A. Elastase-induced emphysema: retention of instilled proteinase in the rat. Am Rev Respir Dis 1982; 126: 914-920.

20. Campbell EJ, White RR, Senior RM, Rodriguez RJ, Kuhn C. Receptor-mediated binding and internalization of leukocyte elastase by alveolar macrophages in vitro. $J$ Clin Invest 1979; 64: 824-833.

21. Dwenger A, Tost P, Holle W. Evaluation of elastase and alpha ${ }_{1}$-proteinase inhibitor-elastase uptake by polymorphonuclear leukocytes and evidence of an elastasespecific receptor. J Clin Chem Clin Biochem 1986; 24 : 299-308.

22. Bartholomew JS, Lowther DA. Receptor-mediated binding of leukocyte elastase by chondrocytes. Arthritis Rheum 1987; 30: 431-438.

23. Breuer R, Christensen TG, Lucey EC, Stone PJ, Snider GL. An ultrastructural morphometric analysis of elastase-treated hamster bronchi shows discharge followed by progressive accumulation of secretory granules. Am Rev Respir Dis 1987; 136: 698-703.

24. Hubbard RC, Brantly ML, Crystal RG. Proteases. In: Crystal RG, West JB, et al., eds. The Lung: Scientific Foundations. New York, NY, Raven Press Ltd, 1991; pp. 1763-1773.

25. Kim KC, Wasano K, Niles RM, Schuster JE, Stone PJ, Brody JS. Human neutrophil elastase releases cell surface mucins from primary cultures of hamster tracheal epithelial cells. Proc Natl Acad Sci USA 1987; 84: 9304-9308.

26. Nadziejko C, Finkelstein I. Inhibition of neutrophil elastase by mucus glycoprotein. Am J Respir Cell Mol Biol 1994; 11: 103-107.

27. Rao NV, Kennedy TP, Rao G, Ky N, Hoidal JR. Sulfated polysaccharides prevent human leukocyte elastase-induced acute lung injury and emphysema in hamsters. Am Rev 
Respir Dis 1990; 142: 407-412.

28. Walsh RL, Dillon TJ, Scicchitano R, McLennan G. Heparin and heparan sulphate are inhibitors of human leukocyte elastase. Clin Sci 1991; 81: 341-346.

29. Kim KC, Lee BC. $\mathrm{P}_{2}$ purinoceptor regulation of mucin release by airway goblet cells in primary culture. $\mathrm{Br} \mathrm{J}$ Pharmacol 1991; 103: 1053-1056.

30. Adler KB, Akley NJ, Glasgow WC. Platelet-activating factor provokes release of mucin-like glycoproteins from guinea-pig respiratory epithelial cells via a lipoxygenasedependent mechanism. Am J Respir Cell Mol Biol 1992; 6: $550-556$.

31. Davis CW, Dowell ML, Lethem M, Van Scott, M. Goblet cell degranulation in isolated canine tracheal epithelium: response to exogenous ATP, ADP and adenosine. Am J Physiol (Cell Physiol 31) 1992; 262: C1313-C1323.

32. Rieves RD, Goff J, Wu T, Larivee P, Logun C, Shelhamer JH. Airway epithelial cell mucin release: immunologic quantitation and response to platelet-activating factor. Am J Respir Cell Mol Biol 1992; 6: 158-167.

33. Lethem MI, Dowell ML, Van Scott M, et al. Nucleotide regulation of goblet cells in human airway epithelial explants: normal exocytosis in cystic fibrosis. $A m J$ Respir Cell Mol Biol 1993; 9: 315-322.

34. Karpf DB, Arnaud CD, Bambino T, et al. Structural properties of the renal parathyroid hormone receptor: hydrodynamic analysis and protease sensitivity. Endocrinology 1988; 123: 2611-2620.

35. Porteau F, Brockhaus M, Wallach D, Engelmann H, Nathan CF. Human neutrophil elastase releases a ligand-binding fragment from the $75 \mathrm{kDa}$ tumor necrosis factor (TNF) receptor: comparison with the proteolytic activity responsible for shedding of TNF from stimulated neutrophils. J Biol Chem 1991; 266: 18846-18853.

36. Tosi MF, Zakem H. Surface expression of Fc gamma receptor III (CD16) on chemoattractant-stimulated neutrophils is determined by both surface shedding and translocation from intracellular storage compartments. $J$ Clin Invest 1992; 90: 462-470.

37. Moulder K, Barton A, Weston B. CD23-mediated homotypic cell adhesion: the role of proteolysis. Eur J Immunol 1993; 23: 2066-2071.

38. Jetten AM. Growth and differentiation factors in tracheobronchial epithelium. Am J Physiol 1991; 260:
L361-L373.

39. Nathan C, Xie Q, Halbwachs-Mecarelli L, Jin WW. Albumin inhibits neutrophil spreading and hydrogen peroxide release by blocking the shedding of CD43 (sialophorin, leukosialin). J Cell Biol 1993; 122: 243-256.

40. Remold-O'Donnell E, Parent D. Two proteolytic pathways for downregulation of the barrier molecule CD43 of human neutrophils. J Immunol 1994; 152: 3595-3605.

41. Nahori M-A, Renesto P, Vargaftig BB, Chignard M. Activation and damage of cultured airway epithelial cells by human elastase and cathepsin G. Eur J Pharmacol Environ Toxicol Pharmacol 1992; 228: 213-218.

42. Kercsmar CM, Davis PB. Resistance of human tracheal epithelial cells to killing by neutrophils, neutrophil elastase, and Pseudomonas elastase. Am J Respir Cell Mol Biol 1993; 8: 56-62.

43. Chung Y, Kercsmar CM, Davis PB. Ferret tracheal epithelial cells grown in vitro are resistant to lethal injury by activated neutrophils. Am J Respir Cell Mol Biol 1991; 5: 125-132.

44. Rickard KA, Taylor J, Rennard SI. Observations of development of resistance to detachment of cultured bovine bronchial epithelial cells in response to protease treatment. Am J Respir Cell Mol Biol 1992; 6: 414420.

45. Lee T-C, Wu R, Brody AR, Barrett JC, Nettesheim P. Growth and differentiation of hamster tracheal epithelial cells in culture. Exp Lung Res 1984; 6: 27-45.

46. Devalia JL, Sapsford RJ, Wells CW, Richman P, Davies RJ. Culture and comparison of human bronchial and nasal epithelial cells in vitro. Respir Med 1990; 84: 303-312.

47. Janoff A. Elastase in tissue injury. Ann Rev Med 1985; 36: 207-216.

48. Bieth JG. Elastases: catalytic and biological properties. In: Mecham RP, ed. Regulation of Matrix Accumulation. Orlando, Academic Press, 1986; pp. 217-320.

49. Amitani R, Wilson R, Rutman A, et al. Effects of human neutrophil elastase and Pseudomonas aeruginosa proteinases on human respiratory epithelium. Am J Respir Cell Mol Biol 1991; 4: 26-32.

50. Fujisawa T, Kephart GM, Gray BH, Gleich GJ. The neutrophil and chronic allergic inflammation: immunochemical localization of neutrophil elastase. Am Rev Respir Dis 1990; 141: 689-697. 